\title{
SETTING THE STAGE: ENHANCING UNDERSTANDING OF BIOETHICAL CHALLENGES WITH THEATRE
}

\author{
Karen H. Rothenberg ${ }^{*}$
}

I. SETTING THE STAGE.................................................... 3

II. WHOSE LIFE IS IT ANYWAY .......................................... 5

III. THE NORMAL HEART ................................................... 11

IV. THE TWILIGHT OF THE GolDS ...................................... 16

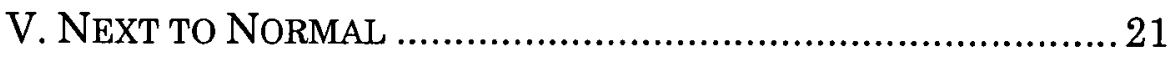

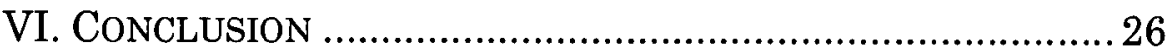

Theatre provides a dynamic platform to reflect upon the ethical, legal and social implications of medical innovations and the powerful impact on personal and professional relationships. From the time of the Ancient Greeks, the drama of these complex interactions on stage has brought to life many emotional challenges-generating hope, fear, and conflicts surrounding identity.

Over the last several years, my colleague Lynn Bush and I have discovered a broad spectrum of plays that we have explored and analyzed in more detail as a creative approach

* J.D., M.P.A., Marjorie Cook Professor of Law and Founding Director, Law and Health Care Program, University of Maryland Francis King Carey School of Law and Visiting Professor, Johns Hopkins Berman Institute of Bioethics, Johns Hopkins University. For the 2013-14 academic year, Professor Rothenberg is serving at the National Institutes of Health as Senior Advisor on Genomics and Society to the Director, National Human Genome Research Institute, and Visiting Scholar, Department of Bioethics, Clinical Center. Professor Rothenberg was the 2013 recipient of the McDonald-MerrillKetcham Memorial Lectureship and Award for Excellence in Law and Medicine. Setting the Stage is an adaptation of the keynote speech by the same name that Professor Rothenberg delivered at the McDonald Merrill Ketcham Award Lecture, sponsored by the Hall Center for Law and Health, Indiana University Robert H. McKinney School of Law, Indianapolis, Indiana, on February 7, 2013. 
to reflect on the role that legal and bioethical principles can play to mediate controversial issues in society. ${ }^{1}$ This work has evolved, in part, from years of trying to figure out how best to engage folks with differing views and perspectives on complex ethical and societal issues. From my experience, the tools used in bioethics and the law have not been enough to bring the issues to life.

As science moves forward at an ever-increasing pace, it becomes more critical to develop creative approaches to better understand the bioethical challenges and to place them in historical and societal context. ${ }^{2}$ With these goals in mind, I set the stage by exploring the last four to five decades of theatre, which coincide with the evolution of the formal discipline of bioethics and the field of medical humanities. Selected excerpts from four plays, one from each decade beginning with the 1970 s and through the beginning of the twenty-first century, are highlighted to reflect the ethical and legal context of their eras. The analysis of the themes that reoccur over time cover one hot topic per decade, each revealing significant ethical challenges for us to ponder.

For the 1970s, we explore Whose Life is It Anyway? ${ }^{3}$ and its focus on the "right to die" and "death with dignity,"

1 KAREN H. RothenBerg \& LYNN W. Bush, THE DRAMA OF DNA: NARRATIVE GENOMICS (forthcoming March 2014) (final book manuscript, on file with authors and Oxford University Press) [hereinafter RoTHENBERG AND BUSH, DRAMA OF DNA]; Karen H. Rothenberg \& Lynn W. Bush, Manipulating Fate: Medical Innovations, Ethical Implications, Theatrical Illuminations, 13 HoUS. J. HEALTH L. \& POL'Y 1 (2012) [hereinafter Rothenberg and Bush, Manipulating Fate]; Karen $\mathrm{H}$. Rothenberg \& Lynn W. Bush, Genes and Plays: Bringing ELSI Issues to Life, 14 GENETICS IN MED. 274 (2012); Karen H. Rothenberg, From Eugenics to the "New" Genetics: "The Play's the Thing," 79 FORDHAM L. REV. 407 (2010) [hereinafter Rothenberg, "New" Genetics]. Substantial portions of this article contain direct quotations and substantive references from Manipulating Fate (selected citations and quotations omitted). In addition to Manipulating Fate, other portions of this article are adapted from the publications noted above and are referenced as applicable.

2 RothenBerg \& BUSH, DRAMA OF DNA, supra note 1, pt. III, ch. 6 , at 3 .

3 BRIAN ClaRK, WhOSE LIFE IS IT ANYWAY? (Dramatic Publishing 1974) (1972). 
followed by The Normal Heart, ${ }^{5}$ an editorial drama about the emergence of, and response to, the AIDS epidemic in the 1980s. The ethical, legal, and social implications of new genomic technologies are examined in the 1990s play The Twilight of the Golds, ${ }^{6}$ followed by Next to Normal, ${ }^{7}$ a 2009 musical dealing with mental illness-a recurrent theme in theatre-and an ongoing challenge for medicine and our society.

\section{SeTting The STAGE}

The formalization of bioethics as a discipline intensified scrutiny of the interplay among science, policy, and the public. ${ }^{8}$ By the late 1960 s and early 1970 s, we gained much perspective on both the benefits and threats of science and technology existing during and after World War II. The double helix was discovered, which opened up the promise for a "new genetics,"9 the birth control pill was prescribed to

4 See generally Rothenberg \& Bush, Manipulating Fate, supra note 1, at 27-29; see also ALAN MEISEL \& KATHY CERMINARA, THE RIGHT TO DIE: THE LAW OF END-OF-LIFE DECISIONMAKING, $\$ \S 2.01,4.01-4.01[\mathrm{c}]$ (3d ed. 2004 \& Supp. 2011).

5 LARRY KRAMER, The Normal Heart, in THE NORMAL HEART AND THE DESTINY OF ME: Two PLAYS BY LARRY KRAMER 1 (2000); see generally Rothenberg \& Bush, Manipulating Fate, supra note 1, at 4042.

6 Jonathan Tolins, The Twilight Of The Golds: A Play In Two ACTS (1992); see generally Rothenberg \& Bush, Manipulating Fate, supra note 1 , at $49-51$.

7 BRIAN YORKEY, NEXT TO NORMAL 32 (2010); see generally Rothenberg \& Bush, Manipulating Fate, supra note 1, at 70-72.

8 TOM L. BEAUCHAMP \& JAMES F. CHILdRESS, PRINCIPLES OF BIOMEDICAL ETHICS 8-9 (6th ed. 2009); RUTH R. FADEN ET AL., A HISTORY AND THEORY OF INFORMED CONSENT 92, 96 (1986); ALBERT R. Jonsen, THE BIRTH OF BIOETHICS (1998); DAVID J. RothMAN, STRANGERS AT THE BEDSIDE: A HISTORY OF HOW LAW AND BIOETHICS TRANSFORMED MEDICAL DECISION MAKING 247-62 (Walter de Gruyter, 2d paperback ed. 2003) (1991).

9 Rothenberg, "New" Genetics, supra note 1, at 410, 422; see also ROTHENBERG \& BUSH, DRAMA OF DNA, supra note 1, pt. III, ch. 6, at 5; Aaron Klug, The Discovery of the DNA Double Helix, 335 J. MOLECULAR BIOLOGY 3 (2004). 
millions of women, ${ }^{10}$ livers and hearts had been transplanted along with the kidneys, the definition of death was debated, and a uniform anatomical gift act was drafted. This all occurred while the civil rights movement was changing our society forever. ${ }^{11}$ It was a time to challenge authority and the government on so many fronts. In 1972, the research abuses of the federally sponsored Tuskegee Syphilis study would make national news with calls for sweeping change about how to ensure the ethical conduct of research in our country. ${ }^{12}$ That same year, the case Canterbury v. Spence affirmed patient autonomy to make medical decisions and spelled out the parameters of informed consent. ${ }^{13}$

Overall, as medical interventions became technologically more complex, the new field of bioethics was framing a number of fundamental questions for society to consider: Is the extension of life beneficial if the individual experiences diminished consciousness or pain? What is the benefit? What is the harm? Who should live and who should die, and who decides? When is it ethical to consider the allocation of scarce resources? How should technology be used to manipulate our fate? What impact would such interventions have on our humanity? What does it mean to be normal and how does our society embrace difference? ${ }^{14}$

These and other medical and ethical challenges presented us with opportunities to evaluate how best to analyze the issues at stake-principles of bioethics and law

10 See John A. McCracken, Reflections on the 50th Anniversary of the Birth Control Pill, 83 BIOLOGY REPROD. 684 (2010); see also JONSEN, supra note 8 , at 12 (summarizing the rapid advances in medical therapies throughout the course of the twentieth century).

11 See Rothenberg, "New" Genetics, supra note 1, at 422-23.

12 See generally TuskegeE'S TRUTHS: RETHINKING THE TUSKEgEE SyPHILIS STUDY (Susan Reverby ed., 2000); TUSKEGEE SYPHILIS STUDY

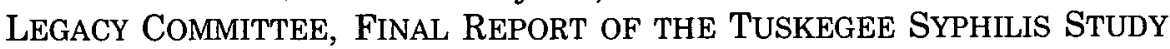
LEGACY COMMITTEE (1996), available at http://www.hsl.virginia.edu/ historical/medical_history/bad_blood/.

$13 \quad 464$ F.2d 772, 783-85 (D.C. Cir. 1972); see generally BEAUCHAMP \& CHILDRESS, supra note 8.

14 Rothenberg \& Bush, Manipulating Fate, supra note 1, at 59. 
would establish respect for persons as a strong value that was grounded on the dignity of the human being, the power of choice and control, and the autonomy of individuals to make their own medical decisions and control the course of their futures. Underlying this autonomy would be the assumption that the individual had the mental capacity to make such decisions. The traditions of professionalism and "doctor knows best" were being reexamined. The principles of beneficence-do what would be best for the patient-and non-maleficence-do no harm-had to find their places in the ethical calculus. Finally, concerns for justice were also to be evaluated in the context of ethical care-along with other questions of personal responsibility, cultural competencies, and interprofessional dynamics. While ethical principles help define issues and provide tools for problem-solving, the law is often called upon in the end to solve, or at least rule, on the issue at stake. ${ }^{15}$

\section{WHOSE LIFE IS IT ANYWAY?}

It is this relationship between ethical principles and the law that is examined in the first play, which was written at a time when legal and ethical foundations of the "right to die" were beginning to evolve for both those patients who had capacity and those who may have needed others to decide on their behalf. 16 In fact, Brian Clark's Whose Life is it Anyway? had a significant role in heightening public awareness on who decides how and when a patient may die, especially given the realities of the power dichotomy in medicine. ${ }^{17}$ The answer to "Whose life is it?" is

15 See generally BEAUCHAMP \& CHILDRESS, supra note 8.

16 See Alan MEISEL \& Kathy CeRminaRa, The Right to DiE: The LAW OF END-OF-LIFE DECISIONMAKING $§ \S ~ 2.01,4.01-4.01[c]$ (3d ed. Supp. 2011).

17 Alexander M. Capron, Foreword to JAY KATZ, THE SILENT WORLD OF DOCTOR AND PATIENT, at xxii-xxiii (Johns Hopkins Press ed., Johns Hopkins Univ. Press 2002) (1984); FADEN ET AL., supra note 8, at 17; Peter G. Filene, In the ARMS of Others: A Cultural History of THE RIGHT-TO-DIE IN AMERICA at xiv-xv, 8-9, 219 (1998); Charles Fried, 
clear from the playwright's perspective: it is the patient's. First written as a play for British television in 1972, it premiered on stage in London in 1978 and a year later on Broadway, followed by a film version in 1981. The protagonist, Ken Harrison, is a young sculptor who was permanently paralyzed from the neck down in an auto accident. Although Ken arrived at the hospital in critical condition, Dr. Emerson and his colleagues stabilized Ken to his current state relying in part on advances in technology, yet Ken decides he no longer wants to live. Unable to physically control his fate, Ken is at the mercy of others to enable him to die. He declares to his medical social worker, Mrs. Boyle:

Ken: Go and convince Dr. Frankenstein that he has successfully made his monster and he can now let it go. . . I I really have absolutely no desire at all to be the object of scientific virtuosity. I have thought things over very carefully. I do have plenty of time for thinking and I have decided that I do not want to go on living with so much effort for so little result. ${ }^{18}$

Mrs. Boyle: We can't just stop treatment, just like that. . .. It's the job of the hospital to save life, not to lose it. . . . It's not unusual, you know, for people injured as you have been, to suffer with this depression for a considerable time before they begin to see that a life is possible. ${ }^{19}$

In fact, Dr. Emerson, who saved Ken's life, now questions Ken's mental state and moves to take steps to use the Mental Health Act to retain Ken. Highlighting the interprofessional tension and emotions over the issues, his younger female colleague, Dr. Scott, begins to question him:

Terminating Life Support: Out of the Closet!, 295 NEW ENG. J. MED. 390, 390-91 (1976).

18 CLARK, supra note 3 , at 30,32 . Ken's reference to Dr. Frankenstein is a nod to an earlier drama. See generally Manipulating Fate, supra note 1, at 3-7, 22-28, 38-48.

19 Id. 
Dr. Scott: But surely a wish to die is not necessarily a symptom of insanity? A man might want to die for perfectly sane reasons. ${ }^{20}$

Dr. Emerson: [A] doctor cannot accept the choice for death; he's committed to life. When a patient is brought into my unit, he's in a bad way. I don't stand about thinking whether or not it's worth saving his life. I haven't the time for doubts. I get in there, do whatever I can to save life. I'm a doctor, not a judge. ${ }^{21}$

Dr. Scott: I hope you will forgive me, sir, for saying this, but I think that is just how you are behaving-as a judge. ${ }^{22}$

Despite the power dynamics, Ken manages to convince Mr. Hill, his attorney, to petition the court for a hearing to be held in the hospital to determine if Ken is being deprived of his liberty and to request that he be allowed to die if found to have, the requisite capacity. ${ }^{23}$ From my perspective, one of the best theatrical dialogues that brings to life the perspectives of both the medical (Dr. Emerson) and legal (Mr. Hill) professions occurs in anticipation of the hearing:

Dr. Emerson: I have every confidence that the law is not such an ass that it will force me to watch a patient of mine die unnecessarily. ${ }^{24}$

Hill: We are just as confident that the law is not such an ass that it will allow anyone arbitrary power. ${ }^{25}$

Dr. Emerson: My power isn't arbitrary; I've earned it with knowledge and skill and it's also subject to the laws of nature. ${ }^{26}$

$\begin{array}{ll}20 & I d . \text { at } 51 . \\ 21 & I d . \\ 22 & I d . \\ 23 & I d . \text { at } 63-66 . \\ 24 & I d . \text { at } 71 . \\ 25 & I d .\end{array}$


Hill: And to the laws of the state. ${ }^{27}$

Dr. Emerson: If the state is so foolish as to believe it is competent to judge a purely professional issue. ${ }^{28}$

Hill: It's always doing that. Half the civil cases in the calendar arise because someone is challenging a professional's opinion. ${ }^{29}$

Dr. Emerson: I don't know about other professions but I do know this one: medicine, is being seriously threatened because of the intervention of law. Patients are becoming so litigious that doctors will soon be afraid to offer any opinion or take any action at all. ${ }^{30}$

Hill: You wouldn't like to find yourself powerless in the hands of, say, a lawyer or a . . bureaucrat. I wouldn't like to find myself powerless in the hands of a doctor. ${ }^{31}$

Dr. Emerson: You make me sound as if I were some sort of Dracula . . . . ${ }^{32}$

Hill: No! . . . I for one certainly don't doubt your good faith but in spite of that I wouldn't like to place anyone above the law. ${ }^{33}$

Dr. Emerson: I don't want to be above the law; I just want to be under laws that take full account of professional opinion. ${ }^{34}$

The playwright sets the stage for the final scene in which the judge is to hear from the doctors, the lawyers,

$\begin{array}{ll}26 & I d . \\ 27 & I d . \\ 28 & I d . \\ 29 & I d . \\ 30 & I d . \\ 31 & I d . \text { at } 72 . \\ 32 & I d . \\ 33 & I d . \\ 34 & I d .\end{array}$


and Ken himself. In this dialogue a number of issues are tackled that we continue to debate today-not only death with dignity, but the implications of our actions on others in society as well:

Judge: You tell me why it is a reasonable choice that you decided to die. ${ }^{35}$

Ken: It is a question of dignity. Look at me here. I can do nothing, not even the basic primitive functions. I cannot even urinate, I have a permanent catheter attached to me. Every few days my bowels are washed out. Every few hours two nurses have to turn me over or I would rot away from bedsores. Only my brain functions unimpaired but even that is futile because I can't act on any conclusions it comes to. ... Will you please listen? ${ }^{36}$

\section{Judge: I am listening. ${ }^{37}$}

Ken: I choose to acknowledge the fact that I am in fact dead and I find the hospital's persistent effort to maintain this shadow of life an indignity and it's inhumane. ${ }^{38}$

Judge: But wouldn't you agree that many people with appalling physical handicaps have overcome them and lived essentially creative, dignified lives? ${ }^{39}$

Ken: Yes, I would but the dignity starts with their choice. If I choose to live, it would be appalling if society killed me. If I choose to die, it is equally appalling if society keeps me alive. ${ }^{40}$

$\begin{array}{ll}35 & I d . \text { at } 78 \cdot 80 . \\ 36 & I d . \\ 37 & I d . \\ 38 & I d . \\ 39 & I d . \\ 40 & I d .\end{array}$


Judge: I cannot accept that it is undignified for society to devote resources to keeping someone alive. 'Surely it enhances that society. ${ }^{41}$

Ken: It is not undignified if the man wants to stay alive, but I must restate that the dignity starts with his choice. Without it, it is degrading because technology has taken over from human will. ${ }^{42}$

The judge rules that Ken is in "complete control of his mental faculties" and signs an order to "set him free," while expressing to Dr. Emerson how sorry he is and understanding how he must feel. ${ }^{43}$

To put this in context, not once during the drama did the playwright let Ken express any doubt about his decision; he was funny, he was angry, but he was always very rational and articulate. Interestingly, and perhaps intentionally, the playwright does not give voice to family or friends to challenge Ken or complicate the issue. Contrary to the medical community's presumption at the time that everyone would welcome the availability of new technology, Ken, and in fact the public, began to question its value to extend life at all costs.

Just a few years after the play premiered, life imitated art and Bouvia v. Superior Court ${ }^{44}$ was decided. Elizabeth Bouvia suffered from cerebral palsy and petitioned the court to prohibit a California hospital from force-feeding her so she could die. She was successful on appeal and found competent to make this decision. Like the court in the play, the court in Bouvia affirmed Bouvia's right to secure her dignity to make the choice and control her destiny as best as she could. ${ }^{45}$ As the decades passed, we

\footnotetext{
$41 \quad I d$. at 80.

42 Id.

43 Id. at 81.

44225 Cal. Rptr. 297, 304-05 (Ct. App. 1986).

45 She decided to exercise her right to remain alive for many years, comforted in knowing that she could change her mind at any time. See Beverly Beyette, The Reluctant Survivor: 9 Years After Helping Her Fight for the Right to Die, Elizabeth Bouvia's Lawyer and Confidante
} 
continued to establish the ethical and legal foundations of a right to die for both those with capacity and for those who could not make their own decisions. We asked ourselves how we could manipulate our fates. From Baby Doe $^{46}$ to Terry Schiavo, ${ }^{47}$ living wills to durable power of attorneys, and ethics committees to statutes and guidelines, we have questioned who should be able to make end-of-life decisions and have debated how those decisions should be made. Many court cases expanded rights and began to tackle assisted suicide, and the debate still continues. ${ }^{48}$

\section{THE NORMAL HEART}

The mid-1980s found both the medical community and the public confronted with a new and poorly understood infectious disease that was raging out of control: acquired immune deficiency syndrome (“AIDS"). 49 Several

Killed Himself - Leaving Her Shaken and Living the Life She Dreaded, L.A. TIMES, Sept. 13, 1992.

46 C. Everett Koop, The C. Everett Koop Papers: Congenital Birth Defects and the Medical Rights of Children: The "Baby Doe" Controversy, U. S. NAT'L LIBR. OF MED., http://profiles.nlm.nih.gov/ ps/retrieve/Collection/CID/QQ (last visited Aug. 25, 2013).

47 See generally Gregory E PENCE, Classic CASES IN MEDICAL Ethics: AcCounts of Cases That HaVe Shaped Medical ETHICS, With PHILOSOPHICAL, LEGAL AND HistoriCAL BACKGROUNDS 29-55 (3d ed. 2000); Sandra H. Johnson et al., Quinlan and Cruzan: Beyond the Symbols, in HEALTH LAW AND BIOETHICS: CASES IN CONTEXT 53-73 (2009); Eric J. Cassell, The Schiavo Case: A Medical Perspective, HASTINGS CENTER REP., May-June 2005, at 22; Rebecca Dresser, Schiavo's Legacy: The Need for an Objective Standard, HASTINGS CENTER REP., May-June 2005, at 20; Jay Wolfson, Erring on the Side of Theresa Schiavo: Reflections of the Special Guardian Ad Litem, HASTINGS CENTER REP., May-June 2005, at 16.

48 See, e.g., Compassion in Dying v. Washington, 850 F. Supp. 1454,1459 (1994) (finding a liberty interest in choice to commit physician-assisted suicide), rev'd, 49 F.3d 586 (1995), aff'd on reh'g en banc, 79 F.3d 790 (1996), rev'd sub nom. Washington v. Glucksberg, 521 U.S. 702, 728 (1997) (finding no liberty interest in choice to commit physician-assisted suicide).

49 See Carol Levine \& Joyce Bermel, AIDS: The Emerging Ethical Dilemmas, in HASTINGS CENTER REPORT (Supp. 1985); see also Ronald 
playwrights seized upon the opportunity to portray the evolution of this mysterious killer that would first grip the gay community and highlight the desperate search to gain control through innovations in medicine.

Larry Kramer's 1985 play The Normal Heart provides a memorable platform for the theatre. Kramer found it very difficult to get the play produced on Broadway at the time, so Joe Papp, the eminent producer, staged it off Broadway at the Public Theatre. This drama was based on Kramer's personal and political experiences working as a gay activist, and he depicts himself in the character of Ned Weeks. ${ }^{50}$ The goal of the playwright is to capture the frustration of medical uncertainty and ethical dilemmas, ${ }^{51}$ in part through the characters of Ned and Dr. Emma Brookner, who was inspired by the life of Dr. Linda Lauberstein, one of the first physicians to treat gay men in New York City during the early days of the epidemic. Ned visits Emma at her medical office:

Ned: In just a couple of minutes you told two people I know something. The article said there isn't any cure. ${ }^{52}$

Emma: Not even any good clues yet. And even if they found out tomorrow what's happening, it takes years to find out how to cure and prevent anything. All I know is this disease is the most insidious killer I've ever seen or studied or heard about. And I think we're seeing only the tip of the iceberg. I'm frightened nobody important is going to give a

Bayer \& Amy L. Fairchild, The Genesis of Public Health Ethics, 18 BIOETHICS 476, 478 (2004).

50 Patrick Healey, Larry Kramer Hand-Delivers His Latest Message, N.Y. TIMES, (Apr. 25, 2011, 11:04 AM), http://artsbeat.blogs.nytimes.com/2011/04/25/larry-kramer-handdelivers-his-latest-message/?_r=0; Letter from Larry Kramer, available at http://www.scribd.com/doc/53626456/PleaseKnow-LarryKramer.

51 See Renée C. Fox, The Evolution of Medical Uncertainty, 58 MilbanK MemoRIal FUND Q. HEALTH \& SoC'Y 1, 13 (1980); Robert Steinbrook et al., Ethical Dilemmas in Caring for Patients with the Acquired Immunodeficiency Syndrome, 103 ANNALS INTERNAL MED. 787 (1985); see also Rothenberg, "New" Genetics, supra note 1, at 411, 426; Rothenberg \& Bush, Manipulating Fate, supra note 1, at 40.

52 KRAMER, supra note 5, at 22. 
damn because it seems to be happening mostly to gay men. ${ }^{53}$

Later in the play, Ned reacts:

Ned: We're all going to go crazy, living this epidemic every minute, while the rest of the world goes on out there, all around us, as if nothing is happening, going on with their own lives and not knowing what it's like, what we're going through. ${ }^{54}$

Kramer's powerful dialogue further dramatizes how attitudes on the morality of homosexuality can blind society to the urgency of addressing a stigmatizing, major public health threat-much like the dynamic witnessed years earlier with the syphilis epidemic also expressed in plays like Ghosts ${ }^{55}$ and Spirochete.56 Stressing that access to health care is a matter of justice, Emma states:

Emma: Health is a political issue. Everyone's entitled to good medical care. If you're not getting it, you have to fight for it. ${ }^{57}$

The Normal Heart captures the complexity of relationships within the gay community, medical profession, and government officials. They all played roles-both positive and negative-in the search for innovative

$53 \quad I d$.

$54 \quad I d$. at 99 .

55 HENRIK IBSEN, GHOSTS, in FOUR MAJOR PlAYS: GHOSTS; AND AN ENEMY OF THE PEOPLE; THE LADY FROM THE SEA 1 (Rolf Fjelde trans., Signet Classics 2d. 1970); see also Rothenberg \& Bush, Manipulating Fate, supra note 1, at 10-11; Rothenberg, "New" Genetics, supra note 1, at $408 \mathrm{n} .2$; ROTHENBERG AND BUSH, DRAMA OF DNA, supra note 1, at pt. III, ch. 6 , at 27 .

56 See ARNOLD SUNDGAARD, SPIROCHETE (1938), available at http://dspace.wrlc.org/doc/bitstream/2041/60699/Spirochetedisplay.pdf, RoNald Bayer, PRIVATE ACTS, SOCIAL CONSEqUENCES: AIDS AND THE Politics of Public Health (1989) Erving GofFMan, Stigma: Notes on THE MANAGEMENT OF SPOILED IDENTITY (1963); see generally Rothenberg \& Bush, Manipulating Fate, supra note 1, at 18-19.

57 KRAMER, supra note 5 , at 25. 
strategies to understand the cause, prevention, and treatment of AIDS. 58 When Ned attempts to convince his gay friends that they must avoid dangerous sexual practices and take personal responsibility for their actions, a theme often expressed during a public health campaign, his colleague Bruce retorts:

Bruce: But we can't tell people how to live their lives! We can't do that. ${ }^{59}$

Ned: You make it sound like that's all that being gay [having sex] means. ${ }^{60}$

And Emma makes clear:

Emma: I don't consider going to the baths and promiscuous sex making love. I consider it the equivalent of eating junk food, and you can lay off it for a while. And yes, I do expect it. 61

Ned: Why are you yelling at me for what I'm not doing? Where's the goddamned AMA in all of this? The government has not started one single test tube of research. ${ }^{62}$

With great frustration, Emma acknowledges the discrimination and unethical practices she is witnessing while she works hard to piece together "treatment of several chemotherapies used together" 63 without success, but this is

58 See Lawrence O. Gostin, HIV Screening in Health Care Settings: Public Health and Civil Liberties in Conflict?, 296 J. AM. MED. ASS'N 2023 (2006); Larry Gostin, Vaccination for AIDS: Legal and Ethical Challenges from the Test Tube, to the Human Subject, Through to the Marketplace, 2 AIDS PUB. POL'Y J. 9 (1987); Beatrix Hoffman, Health Care Reform and Social Movements in the United States, 93 AM. J. PUB. HEALTH 75 (2003).

59 KRAMER, supra note 5 , at 47.

$60 \quad I d$.

$61 \quad I d$. at 72.

62 Id.

$63 \quad I d$. at 85. 
the best she can do to try to help them. Her patients are all guinea pigs with no approved research protocol and no clear course to follow. This is another theme that emerges when trying to address how to respond to new public health threats and medical mysteries, especially among marginalized populations:

Emma: [Y]ou won't get particularly good care anywhere, maybe not even here. At . . . I'll call it Hospital A, you'll come under a group of mad scientists, research fanatics, who will try almost anything and if you die you die . . . you'll just be a statistic for their computer-which they won't share with anyone else, by the way; there's not much sharing going on, never is-you'll be a true guinea pig. At Hospital B, they decided they really didn't want to get involved with this, it's too messy . . . C is like the New York Times and our friends everywhere: square, righteous, superior, and embarrassed by this disease and this entire epidemic." 64

In spite of Emma's best efforts, Ned's lover, Felix, is dying of AIDS, and he shares with Ned his frustration and desperation in losing control of his life:

Ned: Are you ready to get up yet? And eat something?65

Felix: No!-I've had over forty treatments. No!-I've had three, no four different types of chemo. No!-I've had interferon, a couple kinds. I've had two different experimentals. . . . None of it has done a thing. I've had to go into the hospital four times-and please God don't make me go back into the hospital until I die. Eighty-five percent of us are dead after two years. . . Emma has lost so many patients they call her Dr. Death. You cannot force the goddamn sun to come out. ${ }^{66}$

$\begin{array}{ll}64 & I d . \text { at } 85-86 . \\ 65 & I d . \\ 66 & I d . \text { at } 112-13\end{array}$


Yet Felix is not quite ready to give up control of his life. He strives for dignity, for some normalcy; he writes his will, and he and Ned are "married" by Emma in his hospital room shortly before he dies. ${ }^{67}$ As W.H. Auden wrote in his poem September 1,1939, the inspiration for the title of Kramer's play, "[W]hat . . . is true of the normal heart ... [w] must love one another or die."68

As it became clear that AIDS was spreading out of control with no hope in sight, the scientists, physicians, community activists, politicians and society-at-large were struggling to find their moral compass to guide them on how best to control the fate of this disease. Twenty-five years later, The Normal Heart was revived on Broadway to rave reviews, thanks in part to changes in societal attitudes and the passage of time to reflect on new perspectives. Although there is still no cure, the virus had been discovered, treatments were developed, research on a vaccine continued, antidiscrimination and privacy laws were passed, and new prevention strategies were developed. AIDS activists demanded access into research protocols as a means of treatment. The research paradigm shifted from protection against harms to access to benefits, and ethical debates over the access to treatment continue around the world. This challenged us to respond more humanely to social justice issues when confronted with worldwide public health epidemics.

\section{THE TWILIGHT OF THE GOLDS}

By the $1990 \mathrm{~s}$, the development of a "new" genetics, together with concerns about bioethics, had set the stage for the initiation of the Human Genome Project and a major societal challenge: how do we allow the promise of science to move forward and at the same time keep in check the perils of what we learn? ${ }^{69}$ As part of the effort to map the human

67 Id.

68 W.H. Auden, September 1, 1939, The NEW REPUBLIC, Oct. 18, 1939 , at 297.

69 See Eric T. Juengst, The Human Genome Project and Bioethics, 1 KENNEDY INST. ETHICS J. 71 (1991). 
genome, the Project allocated federal funding to establish the Ethical, Legal, and Social Implications ("ELSI") program to "inspire a cohort of ethicists, social scientists, legal scholars and others to address the coming dilemmas associated with increased knowledge about the genome, from social and legal discrimination to more philosophical issues such as genetic determinism." 70

The debates that surround these implications continue to be explored by bioethicists and through popular culture, including theatre. In fact, many of the same debates and questions that surrounded the eugenics movement at the beginning of the twentieth century have been raised. ${ }^{71}$ The vision of an improved society through regulating reproduction continues. ${ }^{72}$ The "new genetics" holds the implicit promise of ending human disease, yet it also "raises familiar questions about the social perception of normality and the potential for discrimination on the basis of race, disability, sexuality, class, and gender." 73

Staged on Broadway in 1993, The Twilight of the Golds by Jonathan Tolins examines the potential exercise of prejudice in the choices surrounding genetics. ${ }^{74}$ Tolins was prompted to hypothesize about the impact of genetic testing for homosexuality after reading two separate studies, both now discredited. 75 The plot centers on Suzanne, who, through fictional cutting-edge technology performed in her husband Rob's lab, discovers that her fetus will very likely be gay. ${ }^{76}$ Early on in the play, even before she gets tested,

70 Francis S. Collins \& Victor A. McKusick, Implications of Human Genome Project for Medical Science, 285 JAMA 540, 541 (2001); see also Rothenberg, "New" Genetics, supra note 1, at 425; Rothenberg \& Bush, Manipulating Fate, supra note 1, at 49; ROTHENBERG \& BUSH, DRAMA of DNA, supra note 1, pt. III, ch. 6, at 1.

71 Rothenberg, "New" Genetics, supra note 1, at 426.

72 Id.

73 Id. at 411.

74 Tolins, supra note 6.

75 Id. One purported to find a scientific basis for inborn homosexuality and the other claimed to isolate differences in a region of the brain between homosexual and heterosexual men. Id.; see also Rothenberg, "New" Genetics, supra note 1, 428.

76 ROTHENBERG \& BUSH, DRAMA OF DNA, supra note 1, pt. III, ch. 6 , at 8 . 
Tolins sets up the tension between David, Suzanne's gay brother who serves as the narrator and her husband, Rob. ${ }^{77}$

David: Face it, Rob, this is [e]ugenics. It's blatant Nazi philosophy. ${ }^{78}$

Rob: Oh, here we go. Every time there's the slightest scientific advance, some knee-jerk liberal starts shouting about the Nazis. We are just trying to make life better. ${ }^{79}$. . . Let's use every weapon we have.... Is that such a horrible thing to think? ${ }^{80}$

The moral dilemma revealed by the idea of genetic testing for certain traits is articulated through the argument between Rob, a geneticist whose work on the Human Genome Project leads him to see a future in which much unnecessary suffering could be avoided through prenatal testing, and David, who analogizes Rob's work to Nazi eugenics. ${ }^{81}$ Rob's company has developed new technology for individual gene identification that would allow parents to terminate fetuses with specific problems or "abnormalities." 22 Alluding to the deceptive perception of genetics as an infallible "code" that defines every human characteristic, Rob does admit:

Rob: [I]t's not like we can point to one gene and say 'aha.' It's the whole composite of evidence that's open to interpretation. ${ }^{83}$

Suzanne: So, it could be a mistake..$^{84}$

Rob: $90 \%$ sure. ${ }^{85}$

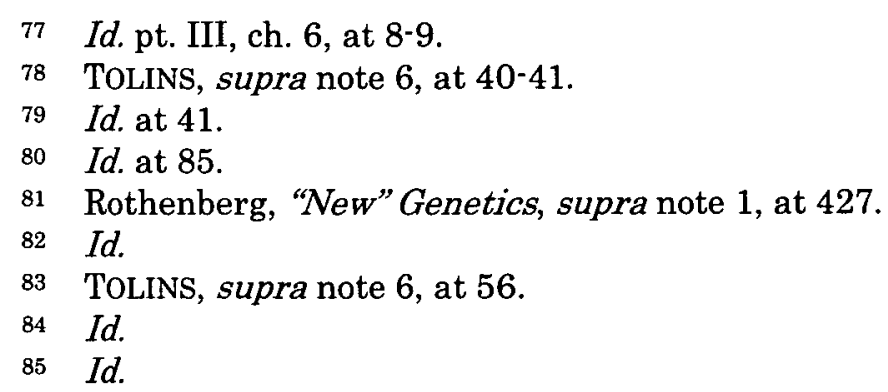


Suzanne: What about environment? I mean if we knew before, couldn't we raise it in a way that . . ${ }^{86}$

Rob: . . . Judging by how clearly it shows up in the statistical evidence, we'd have a lot of nature to nurture against. 87

Clearly, Tolins has brought to life the debate over genetic essentialism and determinism. ${ }^{88}$ In response to Rob, Suzanne shares her hopes and disappointments:

Suzanne: This baby was going to change our lives and make everything better. Not that things are bad ... Now the whole thing is tainted. I wish we didn't know, but we do. And it's a problem. ${ }^{89}$

We can only hope that this would not be the response in 2014, but it is possible that it might be for another trait or condition.

In many ways, the burden of genetic testing rests primarily with the woman, as she is the sole subject of the testing. ${ }^{90}$ The greater knowledge that these technologies provide is accompanied by greater pressure to do as much as possible to give birth to a "perfect and healthy" child. Suzanne is torn between the pressure from her husband, her parents, and society, and her love and respect for her brother David. When she finally decides to abort at five months, it leads to complications that require her to have a hysterectomy. David, once very close to both his sister and parents, never speaks to them again. ${ }^{91}$

\footnotetext{
$86 I d$.

$87 \quad I d$. at 57.

88 Rothenberg, "New" Genetics, supra note 1, at 426-27.

89 Id. at 78.

90 Rothenberg, "New" Genetics, supra note 1, at 427.
}

91 TOLINS, supra note 6 , at 78 . Interestingly, the film version of Tolins' play revises the ending, perhaps to placate mainstream America's aversion to observing abortion. THE TWILIGHT OF THE GoLDS (Fox Lorber 1970) [hereinafter TwILIGHT OF THE GoLDS Film]; see also Rothenberg, "New" Genetics, supra note 1, at 429. In the film, Suzanne decides not to abort the fetus and repairs her relationship 
In an interview, Tolins said that his play asks how "we [are] going to live together if we are suddenly given [a] godlike ability to reshape humanity" and what "criteria are we going to use if we want those we consider undesirable to die."92 These questions are illuminated in a dialogue between David and Suzanne:

David: "[W]hat if you found out the kid was going to be ugly, or smell bad, or have an annoying laugh, or need really thick glasses .... [w] [were do we stop? . . . So now we have this technology, what are we going to do with it?93

Suzanne: Why are you doing this? ${ }^{94}$

David: Because I'm fighting for my life. ${ }^{95}$

Though the research on the "gay gene" has since been firmly rejected, Tolins expresses a prevalent concern for the discriminatory potential of genetic testing, challenging, in this case, the idea that the medical basis of homosexuality would increase tolerance toward individuals who are gay. However, the ethical implications are complex: Though the existence of a gay gene might shift the responsibility from a person's actions to his or her genetic makeup, it could also lead to the biological control of homosexuality. 96 In fact, any attempts to use genetic information to explain behavior will be fraught with conflict. What ever happened to free will?

with her brother. TWILIGHT OF THE GOLDS Film; see also Rothenberg, "New" Genetics, supra note 1, at 429. The film concludes with a flashforward to the baby's happy childhood. TwILIGHT OF THE GOLDS Film; see also Rothenberg, "New" Genetics, supra note 1, at 429.

92 Alvin Klein, Young Playwright Feels Critics' Sting, N.Y. TIMES, Nov. 7, 1993, http://www.nytimes.com/1993/11/07/nyregion/youngplaywright-feels-critics-stings.html?pagewanted $=1$, quoted in Rothenberg, "New" Genetics, supra note 1, at 428.

93 TOLINS, supra note 6 , at 78 .

$94 \quad$ Id. at 79.

95 Id.

96 See Karen H. Rothenberg, The Law's Response to Reproductive Genetic Testing: Questioning Assumptions About Choice, Causation, and Control, 8 FETAL DIAGNOSIS \& THERAPY 160 (1993). 
Tolins imagined and warned of a future in which prenatal genetic screening is commonplace, as it is now, and in which gene-based discrimination is a very real threat, which we hope to have averted to some extent in the employment and health insurance context. In 2008, after more than a decade of debate, Congress passed the Genetic Information Nondiscrimination Act ("GINA"), which prohibits health insurance providers and employers from discriminating based on genetic information and provides certain privacy protections.97 Though GINA does make some progress into addressing concerns about the misuse of genetic information in contexts such as these, it does not address bigger societal concerns, including implications for reproduction of genetic information, reconceptualization of normalcy, tolerance for difference, and the right to an open future.98

\section{NEXT TO NORMAL}

In fact, examining the search for a normal life, a dignified life, and a right to control one's own destiny reveals the tension between bioethical challenges and their solutions-explored in many plays throughout the last few decades, especially the twenty-first century. Brian Yorkey's musical Next to Normal, the 2010 Pulitzer Prize winner in drama,99 depicts the desperate search for medical innovations to control Diana's severe psychiatric bi-polar disorder, her depression with delusional episodes, and her sixteen-year history of medication.

The musical revolves around Diana, her family, and her many doctors' struggle to find her an effective treatment regimen and the implications of these exhausting attempts to get her to function at least "next to normal." Through a

9742 U.S.C. $\$ 2000 \mathrm{ff}-5$ (2013); see also Rothenberg, "New" Genetics, supra note 1, at 426 .

98 Rothenberg, "New" Genetics, supra note 1 , at 426 ; see also Jessica L. Roberts, The Genetic Information Nondiscrimination Act as an Antidiscrimination Law, 86 Notre Dame L. Rev. 597 (2011).

99 The Pulitzer Prizes: Drama, Colum. UNIV., http://www.pulitzer.org/bycat/Drama (last visited Oct. 24, 2013). 
series of powerful musical numbers and dialogue, Diana and the psychiatrists explore how the evolving list of different medical interventions from psychopharmacology to hypnosis to electroconvulsive therapy ("ECT") may control her fate, and theirs, for better or for worse. Diana sets the stage for her desperation. She is trying to balance the risks and benefits of treating mental illness, which often leads to ethical challenges:

Diana: Do you wake up in the morning

And need help to lift your head?

Do you read obituaries

And feel jealous of the dead?

It's like living on a cliffside

Not knowing when you'll dive...

Do you know

Do you know what it's like to die alive?100

Yorkey sets up the context for challenges faced by Diana, her doctors, and her family. After so many years experimenting with different drugs, it is clear that there is no quick fix. In song, Diana and her psychiatrist, Dr. Fine, describe it well:

Dr. Fine: The round blue ones with food but not with the oblong white ones. The white ones with the round yellow ones but not with the trapezoidal green ones. Split the green ones into thirds with a tiny chisel. ${ }^{101}$

Diana: I've got less anxiety, but I have headaches, blurry vision, and I can't feel my toes. ${ }^{102}$

Dr. Fine: So we'll try again, and eventually we'll get it right. ${ }^{103}$

Diana: Not a very exact science, is it? ${ }^{104}$

100 Yorkey, supra note 7 , at 32.

101 Id. at 17.

102 Id. at 18.

103 Id. 
Unfortunately, it is not an exact science. And this reality. can pose ethical dilemmas along with trying to sort out who gets to decide what is "right" and for whom? There is often a trade-off for the patient in trying to achieve even a semblance of normalcy with medication to survive within the family and in society-and in missing the person you think you really are-especially with the highs. Diana reflects in song:

Diana: All these blank and tranquil years -

Seems they've dried up all my tears. . . .

But I miss the mountains.

I miss the dizzy heights.

All the manic, magic days,

And the dark depressing nights. ...

Mountains make you crazy -

Here it's safe and sound.

My mind is somewhere hazy -

My feet are on the ground....

I miss the mountains ...

I miss my life. ${ }^{105}$

Diana's condition gets worse, and she and her husband Dan visit yet another psychiatrist, Dr. Madden. They are desperate for answers and explanations about Diana's past and her family:

Dr. Madden: Often the best we can do is put names on collections of symptoms. It's possible bipolar has more-in common with schizophrenia than depression. ${ }^{106}$

Diana: When I was young, my mother called me "highspirited." She would know. She was so high-spirited they banned her from the PTA. ${ }^{107}$ 
Dr. Madden: Sometimes there's a predisposition to illness, but actual onset is only triggered by some .. . traumatic event. ${ }^{108}$

In fact, we soon discover that Diana's deepening depression was over the death of her infant son years ago, which intensifies her biopolar episodes. Unable to cope with all the medicines and her mounting sadness, she attempts suicide and is rushed to the hospital. Doctor Madden recommends ECT, or shock therapy for short, calmly stating to Dan:

Dr. Madden: The modern procedure's clean and simple. Hundreds of thousands of patients receive it every year. ${ }^{109}$ We can administer the ECT and you can bring her home in ten days. Or we can keep her sedated for forty-eight hours, then discharge her and wait for her to try again. ${ }^{110}$ Legally, we need her consent. Hospital policy is we need yours, too. ${ }^{111}$

Dan: I don't think she's gonna go for this. ${ }^{112}$

But in desperation, she does go for it. The play exposes us to the ethical issues at stake when trying to secure informed consent and determine decision-making capacity for individuals with psychiatric conditions. ${ }^{113}$ In fact, in an interview, Yorkey shared that it was an article about mental illness and the administration of ECT over a decade prior that sparked his interest in writing the musical.114

108 Id.

109 Id. at 56.

$110 I d$. at 53.

111 Id.

$112 I d$.

113 Thomas Grisso \& PaUl S. Appelbaum, Assessing Competence to Consent to Treatment: A GuIde fOR PHysicians and OTHER HEALTH PROFESSIONALS (1998).

114 Patricia Cohen, Mental Illness, the Musical, Aims for Truth, N.Y. TIMES (Apr. 16, 2009), http://theater.nytimes.com/2009/04/19/ theater/19cohe.html?pagewanted=all\&_r=0 (last visited Aug. 30, 2013). 
ECT has a long and controversial past, and the pendulum of public opinion has swung back and forth, both in response to early abuses and, more recently, to guidelines and strict rules for administering ECT, often limited to being a last resort. The new guidelines have been implemented along with extensive informed consent processes. ${ }^{115}$ As Yorkey reminds us of One Flew Over the Cuckoo's Nest from the 1960's, ${ }^{116}$ Diana sings:

Diana: Didn't I see this movie, With McMurphy and the nurse?

That hospital was heavy

But this cuckoo's nest is worse. ${ }^{117}$

In recent years and with major advancements in the technology, ECT has been considered a life-saver for many suffering from severe depression. ${ }^{118}$ Ironically, it also raises new ethical challenges for ensuring that access to the therapy is available for those who want it and can prove that they have the capacity to consent.

For Diana, ECT is not the cure. Frustrated after weeks of memory loss, she reflects with Dr. Madden on all that she has tried, with limited success:

Diana: They told me that the wiring

Was somehow all misfiring

And screwing up the signals in my brain.

And then they told me chemistry,

The juice, and not the circuitry,

115 See generally THE ECT HANDBOOK 12 (Allan I.F. Scott ed., Bell \& Bain Limited 2d ed. 2005); Matthew V. Rudorfer et al., Electroconvulsive Therapy, in PSYCHIATRY 1865-901 (Allan Tasman et al. eds., 2003).

116 KEN KESEY, ONE FLEW OVER THE CUCKOO'S NEST (1962); see generally Rothenberg \& Bush, Manipulating Fate, supra note 1 , at $26^{-}$ 27.

117 YORKEY, supra note 7, at 56.

118 Leon E. Rosenberg, Brainsick: A Physician's Journey to the Brink, Cerebrum (Oct. 1, 2002), http://www.dana.org/news/cerebrum/ detail.aspx?id=2884 (last visited Oct. 28, 2013). 
Was mixing up and making me insane ...119

Dr. Madden: Relapse is very common, Diana...

Stay with me.

Try again.

Is medicine magic? You know that it's not.

We know it's not perfect, but it's what we've got. ${ }^{120}$

Ethically, it was important that the psychiatrist not give up on the patient. And in the end, Diana is well enough to express her feelings to her daughter Natalie, who has been struggling with the impact of her mother's mental illness on her life:

Diana: We wanted to give you a normal life, but I realize I have no clue what that is. ${ }^{121}$

Natalie: I don't need a life that's normal-

That's way too far away.

But something ... next to normal

Would be okay. ${ }^{122}$

\section{CONCLUSION}

We are left with fundamental ethical questions brought to life by all of these plays: What is normal? And who decides? Characters in theatre dramatize both the promises and perils of medical interventions, and the uncertainties of our futures, be they in the context of a dignified death, a public health epidemic, new genetic technologies, or treatments for mental illness. What does it mean to live a normal life? How can we control our fate? What impact will our decisions have on our family, professionals and society? These are questions that set the stage for the next Act. Hopefully, they will stimulate discussion among our colleagues on how theatre may

119 YoRKEY, supra note 7, at 89.

120 Id. at 90.

121 Id. at 94.

122 Id. 
further enhance our understanding of the bioethical challenges we face together. 
